Justyna Szablewska

(Di) https://orcid.org/0000-0001-6231-7554

Uniwersytet Wrocławski

\title{
Solidarność ze społecznością lokalną jako motyw działalności członków Ochotniczej Straży Pożarnej w Dzikowcu w latach I945-2012
}

(di) https://doi.org/10.15633/9788374389952.10

Ochotnicze Straże Pożarne odgrywają istotną rolę w społecznościach lokalnych. W zakresie ich działalności od początku mieściły się nie tylko akcje ratowniczo-gaśnicze, ale również propagowanie wartości humanitarnych i patriotycznych, kultury, sportu. Funkcjonowały przede wszystkim na terenie wsi oraz małych miast. Przyczyniały się do integracji miejscowej społeczności. Z niej wywodzili się także sami strażacy. Członkowie OSP utrzymywali się głównie $\mathrm{z}$ rolnictwa lub pracy w przemyśle. Pożarnictwo stanowiło ich pasję. Niejednokrotnie sami zainteresowali się tą tematyką ze względu na pełnienie tej służby przez członków rodzin, a także starali się też przekazywać ideę strażackich szeregów następnym pokoleniom.

\section{Historia ochotniczego ruchu strażackiego}

Powstanie i rozwój ochotniczych straży ogniowych na terenach Rzeczypospolitej pod zaborami datuje się na połowę XIX wieku. Wcześniej jednak powstawały także stowarzyszenia skupiające się na zagadnieniach związanych z ochroną przeciwpożarową. Jednym z nich było Stowarzyszenie Ratunkowe od Ognia, założone w Warszawie w 1800 roku. Najmocniejszy rozwój ochotniczych straży ogniowych miał miejsce pod zaborem austriackim, gdzie społeczeństwo miało stosunkowo dobre warunki do rozwoju polskich stowarzyszeń. Pod zaborem niemieckim przeważały obowiązkowe straże ogniowe, organizowane zarówno w miastach, jak i na wsiach. Ze sporymi 
trudnościami rozwijały się straże ochotnicze pod zaborem rosyjskim. Strażacy ochotnicy wnieśli istotny wkład w odbudowę państwa polskiego. Uczestniczyli w Powstaniu Wielkopolskim, powstaniach śląskich oraz w wojnie z bolszewikami w latach 1919-1921. W 1921 roku strażacy zjednoczyli wszystkie związki działające pod zaborami w jeden Główny Związek Straży Pożarnych RP. Działali w myśl hasła widniejącego na ich sztandarach: „W jedności siła”. Przyczyniali się do budowy i rozwoju II Rzeczypospolitej. Podczas drugiej wojny światowej na różnych polach czynnie walczyli z wrogami. 23 grudnia 1939 roku utworzyli Strażacki Ruch Oporu „Skała”. W organizacji tej działał np. Bolesław Chomicz. Ponadto uczestniczyli w ochronie przeciwpożarowej na rodzimych terenach.

Po zakończeniu drugiej wojny światowej OSP powstają samorzutnie, bazując na doświadczeniach wyniesionych z II Rzeczypospolitej. Towarzyszy temu zapał i potrzeba zapewnienia bezpieczeństwa lokalnej społeczności. W wielu miejscowościach brakowało sprzętu. Mimo to strażacy stawali do walki z żywiołami. Wspólne przeżycia przyczyniały się do integracji członków jednostek pomimo różnego ich pochodzenia oraz traumatycznych, wojennych doświadczeń. 30 listopada 1945 roku ukazało się zarządzenie ministra administracji publicznej o ustanowieniu zarządu przymusowego Związku Straży Pożarnych. Ograniczano samorządność i samodzielność Związku. Nie zgadzał się z tym prezes Zarządu Przymusowego Związku Straży Pożarnych RP Bolesław Chomicz, który w grudniu 1947 roku zrezygnował z funkcji. Dwa lata później Związek Straży Pożarnych RP został rozwiązany ${ }^{1}$. Skupiał w tym roku już 12834 OSP z liczbą 387 o50 członków. Aktywną działalność prowadziło 15 okręgów wojewódzkich oraz 270 oddziałów powiatowych. Poza tym poza strukturą Związku funkcjonowało 735 straży przymusowych, 969 przemysłowych zawodowych, 175 kolejowych, 73 zawodowych miejskich oraz 3 straże leśne ${ }^{2}$. Zagadnienia ochrony przeciwpożarowej przeniesiono na nowo utworzone komendy straży. Przedwojenna generacja działaczy była odsuwana od pełnienia kierowniczych funkcji w jednostkach terenowych. Kwestia bezpieczeństwa pożarowego w państwie wymagała dość pilnego uregulowania. W związku z tym w 1950 roku ukazała się pierwsza w nowej Polsce ustawa o ochronie przeciwpożarowej ${ }^{3}$. Po 1956 roku,

1 Rozporządzenie Rady Ministrów z dnia 29 października 1949 roku w sprawie rozwiązania stowarzyszenia wyższej użyteczności Związek Straży Pożarnych Rzeczypospolitej Polskiej.

2 S. Kuta, Ochotnicze straże pożarne w Polsce Ludowej 1944-1975, Warszawa 1987, s. 8o.

3 Ustawa $\mathrm{z}$ dnia 4 lutego 1950 roku o ochronie przeciwpożarowej i jej organizacji. 
w związku z odwilżą, następowała powolna odbudowa ruchu strażackiego. Zezwolono na działalność Związku OSP odgrywającego istotną rolę w funkcjonowaniu ruchu strażackiego. 28 grudnia 1956 roku odbył się w Warszawie Krajowy Zjazd Delegatów Ochotniczych Straży Pożarnych, który podjął uchwałę o powołaniu do życia Związku OSP, a także dokonał wyboru Tymczasowego Zarządu Głównego. Wzorcowy statut OSP opublikowano w 1957 roku ${ }^{4}$. Przygotowanie ludności do zadań w zakresie ochrony przeciwpożarowej nadal należało do zadań stowarzyszenia. W 1958 roku Związek OSP uznany został za stowarzyszenie wyższej użyteczności ${ }^{5}$ oraz uzyskał nowy statut. Podczas zjazdu 24-25 października 1959 roku przyjęto społecznikowskie hasło programowe: „Praca dla społeczeństwa i ze społeczeństwem” ${ }^{6}$ W 1960 roku powstała nowa ustawa o ochronie przeciwpożarowej ${ }^{7}$.

Statut z 1958 roku stanowił między innymi, że „zadaniem Związku jest pobudzanie i wszechstronne rozwijanie wszelkiej inicjatywy zmierzającej do zwiększenia udziału społeczeństwa w ochronie przeciwpożarowej”. Należało zatem szukać partnerów do społecznej działalności, jeszcze mocniej otworzyć się na społeczność lokalną. Nie tylko ochraniać ją przed skutkami żywiołów, ale także edukować w kwestii tego, jak im zapobiegać. W związku z tym OSP mocniej otworzyła się na młodzież oraz kobiety. W jednostkach liczniej powstawały osobne drużyny skierowane do tych grup. W 1946 roku w samym województwie wrocławskim działało już 110 drużyn kobiecych. Rozwiązanie Związku w 1949 roku oznaczało także likwidację wielu z nich i w kraju pozostało jedynie kilkadziesiąt tego rodzaju zespołów. Sytuację starała się ratować Komenda Główna Straży Pożarnych, wydając w 1952 roku stosowne zarządzenie ${ }^{8}$. Niestety nie przyniosło to pozytywnego rezultatu. Przełomowy okazał się 1964 rok, od którego rozpoczęło się znaczne zaangażowanie kobiet w pożarnictwo. Stało się to za sprawą uchwały II Walnego Zjazdu OSP, który upatrywał w aktywności kobiet efektów profilaktyki przeciwpożarowej. Organizacja drużyny stanowiła wewnętrzną sprawę

4 Zarządzenie ministra spraw wewnętrznych z dnia 18 lipca 1957 roku w sprawie ustalenia statutu wzorcowego ochotniczej straży pożarnej.

5 Rozporządzenie Rady Ministrów z dnia 14 sierpnia 1958 roku w sprawie uznania stowarzyszenia Związek Ochotniczych Straży Pożarnych za stowarzyszenie wyższej użyteczności.

6 P. Matusak, Tradycje i profil ideowy ruchu strażackiego w Polsce, w: Zeszyty historyczne Zwiazku Ochotniczych Straży Pożarnych Rzeczypospolitej Polskiej. „Z dziejów Ochotniczych Straży Pożarnych”, red. J. Gmitruk, P. Matusak, Warszawa 2007, t. 6, s. 35.

7 Ustawa $\mathrm{z}$ dnia 13 kwietnia 1960 roku o ochronie przeciwpożarowej.

8 Rozkaz komendanta głównego $\mathrm{nr}$ 5/52 z dnia 29 lutego 1952 roku w sprawie kobiet w ochronie przeciwpożarowej. 
OSP, przy której była ona tworzona. Dopiero w 1965 roku ukazał się regulamin wzorcowy kobiecej drużyny OSP, zmodyfikowany w 1970 roku. Poprawiła się jakość pracy, ale nie było efektów ilościowych. Społeczeństwo nie zawsze przychylnie odnosiło się do aktywności pań w OSP. Kłopot z drużynami żeńskimi polegał również na płynności kadr. Kobiety przejawiały aktywność przeważnie do czasu założenia własnej rodziny. Później, w miarę przybywania kolejnych obowiązków rodzinnych oraz zawodowych, ilość dostępnego czasu na działalność społeczną znacząco spadała. Angażowanie kobiet do działalności na rzecz ochrony przeciwpożarowej następowało także przez Koła Gospodyń Wiejskich. Najczęściej były to kontakty oparte na relacjach rodzinnych i sąsiedzkich.

Nowy okres w rozwoju jednostek i ich organizacji rozpoczął się po 1989 roku, po przemianach ustrojowych. W 1991 roku uchwalona została ustawa o ochronie przeciwpożarowej. Rok później zrzeszenie zmieniło nazwę na Związek Ochotniczych Straży Pożarnych Rzeczypospolitej Polskiej. Na jego czele stanął Waldemar Pawlak, który sprawuje funkcję prezesa do dziś. W swojej działalności stara się pobudzać w ZOSP RP idee głoszone przez Bolesława Chomicza - apolityczność, pracę społeczną, samorządność, humanitaryzm, służbę dla społeczności lokalnej, dbałość o dobro wspólne. Ponadto upatrywał w OSP potencjału do edukowania okolicznych mieszkańców w zakresie nowych technologii ${ }^{9}$. W połowie lat 9o. ubiegłego stulecia kobiety uzyskały pełnię praw strażaka - zarówno społecznej, jak i zawodowej służby. Mogły podejmować naukę w systemie codziennym w szkołach pożarniczych, a widok kobiety w zespołach ratowniczych budził już zdecydowanie mniejsze zaskoczenie. Gwałtownie wzrastała liczba akcji gaśniczych. W 1990 roku odnotowano 53706 pożarów, a po upływie 10 lat - już 133492. W 1997 roku rozpoczęto tworzenie Krajowego Systemu Ratowniczo-Gaśniczego, do którego weszła znaczna część OSP. Ponadto wciąż przyjmowane są kolejne jednostki. System obejmuje walkę z pożarami, a także ratownictwo techniczne, chemiczne, wodne, ekologiczne, radiacyjne oraz medyczne. Jednostki zmodyfikowały formy swojej działalności, ale nie idee przyświecające służbie społeczeństwu ${ }^{10}$. Obecnie strażak to profesja największego zaufania społecznego. Podobnie jak w poprzednich latach przypisuje się mu funkcje

9 P. Matusak, Trwałość idei Bolesława Chomicza w polskim ruchu strażackim, w: Zeszyty historyczne Związku Ochotniczych Straży Pożarnych Rzeczypospolitej Polskiej. „Z dziejów Ochotniczych Straży Pożarnych”, red. J. Gmitruk, P. Matusak, t. 7, Warszawa 20o8, s. 16.

10 P. Matusak, Tradycje i profil ideowy..., dz. cyt., s. 36-38. 
ratownicze, służebne wobec człowieka w potrzebie. Członkostwo w OSP jest kojarzone z kultywowaniem wartości humanitarnych, ofiarną służbą dla lokalnej społeczności. Pozostaje w kontrze do upowszechnianego wzorca egoistycznej troski o własne dobro, indywidualny interes. Nie bez znaczenia jest też fakt, że często strażnica stanowi jedyne miejsce spotkań na terenie wsi ${ }^{11}$.

\section{Ochotnicza Straż Pożarna w Dzikowcu}

Dzikowiec to wieś w województwie dolnośląskim, w powiecie kłodzkim, usytuowana w dolinie rzeki Dzik, między Masywem Dzikowca a Górami Sowimi. Pierwsze informacje o miejscowości pochodzą z 1337 roku. W 1390 roku część wsi zakupili augustianie z Kłodzka. Z czasem zakonnicy stali się największymi właścicielami dóbr w miejscowości. W 1597 roku własność augustianów przejęli kłodzcy jezuici. Po 29 latach należała do nich już cała wieś. Jako pierwsi utworzyli we wsi kopalnię węgla kamiennego. Po kasacie zakonu jezuitów dobra przejęli ostatecznie właściciele ziemscy. Czerpali przy tym dochody z miejscowej kopalni. Wydobycie trwało we wsi do końca XIX wieku. W okresie międzywojennym największy zakład na terenie wsi stanowiły kamieniołomy. Po drugiej wojnie światowej jako pierwsi osiedlili się w Dzikowcu robotnicy przymusowi. Zaczęli napływać też Polacy z centralnej części kraju oraz przesiedleńcy z Kresów. Z drugiej strony teren opuszczali dotychczasowi niemieccy mieszkańcy. Wówczas w integrującej się społeczności narodziła się inicjatywa obywatelska dotycząca stworzenia formy ochrony przed zagrożeniem pożarowym. W latach 1975-1998 miejscowość pod względem administracyjnym należała do województwa wałbrzyskiego.

W grudniu 1945 roku podjęto pierwsze rozmowy na temat utworzenia we wsi OSP. Organizacja powstała, ale bez zarządu. Szybko okazało się, że do sprawnego funkcjonowania organizacji nie wystarczy solidarność społeczna. Oprócz zrywów związanych z akcjami trzeba było również regularnie poświęcać czas na bieżącą prace w jednostce - np. konserwację sprzętu pożarniczego. Na tego rodzaju działania z czasem brakowało zapału. Strażacy doszli do wniosku, że potrzebny jest nadzór oraz kierownictwo, które obejmą całokształt funkcjonowania jednostki. 27 stycznia 1946 roku w Knurowie, dzisiejszym Dzikowcu, odbyło się pierwsze zebranie wyborcze.

11 T. Pilch, Refleksje nad społecznymi i filozoficznymi przesłankami ksztattowania się wspólnoty i spoteczeństwa obywatelskiego oraz jego wybranych organizacji, w: Analizy Strategiczne Florian 205o, red. M. Zalewski, Warszawa 2020, t. 2, s. 102. 
Uczestniczyło w nim 21 członków zwyczajnych oraz 6 wspierających. Pierwszym prezesem OSP został Franciszek Łoś, jego zastępcą - Wojciech Chamielec, naczelnikiem - Andrzej Florkiewicz, zastępcą naczelnika - Walenty Dura, skarbnikiem - Józef Wszotek, sekretarzem - Rudolf Małysz, gospodarzem - Emil Truchły. W skład komisji rewizyjnej weszli Władysław Tomasik oraz Kazimierz Stępień. W szeregi jednostki zostało przyjętych 23 członków. Najstarszy - Wojciech Chamicki - miał 37, a najmłodszy - Józef Kuś - 18 lat. Pochodzili z różnych stron kraju. Za jedną z pilnych spraw uznane zostało uporządkowanie i adaptacja poniemieckiej stodoły na remizę. Budynek ten służy OSP do dziś. W czasie zebrania omawiano także kwestię przeprowadzania ćwiczeń ${ }^{12}$. Początkowo strażacy nie dysponowali zaawansowanym sprzętem pożarniczym. Wyjeżdżali do akcji zaprzęgiem konnym wyposażonym w sikawkę ${ }^{13}$. Aby poprawić ten stan rzeczy, ochotnicy potrzebowali pieniędzy. W związku z tym postanowili zorganizować imprezę, która przyniesie im odpowiedni dochód ${ }^{14}$.

Zarząd OSP sprawował władzę przez niespełna miesiąc. Nie udało się uzyskać wśród strażaków odpowiedniej dyscypliny - nie wywiązywali się ze swoich obowiązków. Ponadto problem organizacyjny stanowiła sytuacja typowa dla OSP na Ziemiach Odzyskanych - duży napływ nowych członków, którzy po krótkim czasie licznie rezygnowali z powodu zmiany miejsca zamieszkania. 22.02.1946 roku odbyło się kolejne zebranie wyborcze. Prezesem został Wojciech Chamielec, naczelnikiem - Józef Matusiewicz, zastępcą naczelnika - Walenty Dura, skarbnikiem - Józef Wszotek, sekretarzem - Rudolf Małysz, adiutantem - Franciszek Jugowiec. W skład komisji rewizyjnej weszli: Józef Adamkiewicz, Zygmunt Wajdeczko, Ludwik Frątczak. Wybór nowych władz poskutkował ożywieniem działalności społecznej w jednostce. Natychmiast ukończono uporządkowywanie remizy. Sporządzono nową listę członków OSP ${ }^{15}$. Organizacja liczyła w swoich szeregach 22 członków. Byli nimi mężczyźni, zamieszkali w ówczesnym Knurowie, w wieku od 18 do 37 lat $^{16}$. Ponadto uzgodniono, że ćwiczenia pożarnicze w okresie zimowym

12 ży Pożarnej w Dzikowcu.

13

14

15

Protokół z zebrania Ochotniczej Straży Pożarnej z dnia 27.01.1946 r., Archiwum Ochotniczej StraCharakterystyka OSP Dzikowiec, Archiwum Ochotniczej Straży Pożarnej w Dzikowcu.

Protokół z zebrania Ochotniczej Straży Pożarnej z dnia 27.01.1946..., poz. cyt.

Protokół zebrania miesięcznego Ochotniczej Straży Pożarnej z dnia 22.02.1946 roku, Archiwum Ochotniczej Straży Pożarnej w Dzikowcu.

Wykaz członków Ochotniczej Straży Pożarnej w Knurowie - stan z dnia 24.02.1946 roku, Archiwum Ochotniczej Straży Pożarnej w Dzikowcu. 
będą odbywały się co niedzielę między godz. 14.oo a 16.oo. Ponadto w każdą pierwszą niedzielę miesiąca miało odbywać się zebranie członków OSP ${ }^{17}$. Strażacy starali się uzyskać jak najlepsze relacje z mieszkańcami wsi. Organizowali festyny, zabawy taneczne oraz loterie fantowe. Okoliczna ludność przychylnie odnosiła się do ich działalności i wspierała podczas różnych zbiórek pieniędzy ${ }^{18}$. Z czasem ochotnicy wyjeżdżali na akcję wozem rekwizytowym z motopompą, który był ciągnięty przez konie lub ciągnik rolniczy ${ }^{19}$.

Zachowana $\mathrm{w}$ jednostce dokumentacja dotycząca kolejnych lat jest bardzo skąpa. Wiadomo, że w czasie zebrania sprawozdawczo-wyborczego 14 lutego 1965 roku OSP liczyła 13 członków - dorosłych mężczyzn. Funkcje prezesa na kolejną kadencję objął 43-letni górnik Antoni Mądraszek. Poza tym w składzie zarządu znalazł się naczelnik Władysław Matusiewicz, wiceprezes Józef Matusiewicz, skarbnik Zenon Dobras, sekretarz Józef Kozakiewicz oraz gospodarz Antoni Bednarek. Do komisji rewizyjnej zostali wybrani: Jerzy Baranowski, Władysław Knop, Michał Materna ${ }^{20}$. Jednostka aktywnie angażowała się działalność kulturalno-oświatową ${ }^{21}$. Członkowie OSP społecznie plantowali plac pod ogródek jordanowski ${ }^{22}$. W 1968 roku jednostka otrzymała fabrycznie nowy samochód gaśniczy marki Żuk z pełnym wyposażeniem gaśniczym ${ }^{23}$. W tym czasie w skład jednostki wchodziła już drużyna młodzieżowa ${ }^{24}$. Młodzi strażacy nie tylko w chwilach zagrożenia wspomagali akcje gaśnicze oraz przeciwpowodziowe, ale także reprezentowali jednostkę w licznych zawodach sportowo-pożarniczych. Jej przedstawiciele byli kilkukrotnie laureatami różnego szczebla Ogólnopolskiego Turnieju Wiedzy Pożarniczej „Młodzież zapobiega pożarom” ${ }^{25}$. W rywalizacji podczas zawodów brała udział także Kobieca Drużyna Pożarnicza OSP w Dzikowcu ${ }^{26}$.

1 marca 1970 roku prezesem oraz przedstawicielem Gminnej Rady Narodowej wybrany został górnik Stanisław Turkiewicz. Do zarządu wybrani

\footnotetext{
17 Protokół zebrania miesięcznego Ochotniczej Straży Pożarnej z dnia 22.02.1946 roku..., poz. cyt.

26 Kronika Ochotniczej..., dz. cyt., s. 10.
} 
zostali także: naczelnik Michał Materna, wiceprezes Mieczysław Barczewski, skarbnik Zenon Dobras, sekretarz Kazimierz Lewandowski, gospodarz Józef Matusiewicz. W skład komisji Rewizyjnej weszli: Stanisław Knop, Józef Ryśkiewicz, Jan Szatkowski. Jednostka liczyła 18 członków czynnych oraz 7 osób zrzeszonych w drużynie młodzieżowej ${ }^{27}$. W czasie sprawowania funkcji prezesa Turkiewicz był również Komendantem Miejsko-Gminnym Straży Pożarnych w Nowej Rudzie ${ }^{28}$. W związku z tym do jednostki trafił sztandar Zarządu Miejsko-Gminnego ZOSP ${ }^{29}$. Strażacy angażowali się w działalność prewencyjną skierowaną do okolicznych mieszkańców - wygłaszali pogadanki profilaktyczne w szkołach i na zebraniach wiejskich. Ponadto rozdawali ulotki w Dniu Ochrony Przeciwpożarowej. W 1972 roku jednostka liczyła 22 członków czynnych. Drużyna młodzieżowa oraz kobieca zrzeszały po 8 osób $^{30}$. W 1983 roku jednostka otrzymała Stara 244. W związku z tym, Żuk został przekazany innej straży w gminie ${ }^{31}$. W 1986 roku organizacja liczyła 12 członków. Nie istniała zarówno drużyna młodzieżowa, jak i kobieca. Funkcje naczelnika pełnił Wiesław Knop, wiceprezesa - Bolesław Urbański, skarbnika - Zenon Dobras, sekretarza - Mieczysław Bedychaj, gospodarza - Władysław Małusiewicz. W skład komisji rewizyjnej wchodzili Józef Ryśkiewicz oraz Michał Smoleński ${ }^{32}$. Po upływie 2 lat liczba członków czynnych wzrosła do 23. Poprawiła się współpraca z otoczeniem. Reaktywowana została działalność drużyny młodzieżowej. W skład jednostki wchodziło 5 członków popierających, którzy postanowili finansowo wspierać jej działalnośćc ${ }^{33}$. Stanisław Turkiewicz na kilka dni przed swoją śmiercią w 1998 roku został odznaczony Honorowym Medalem im. Bolesława Chomicza.

Kolejnym prezesem OSP w Dzikowcu został Henryk Srokowski ${ }^{34}$. W styczniu 2007 roku został on wybrany także prezesem Zarządu Oddziału Miejsko-Gminnego Związku OSP RP w Nowej Rudzie. Sprawę współpracy

27 Protokół walnego zebrania z dnia 1.03.1970 roku, Archiwum Ochotniczej Straży Pożarnej w Dzikowcu.

28 Charakterystyka OSP..., poz. cyt.

29 Kronika Ochotniczej..., dz. cyt., s. 6.

30 Sprawozdanie z działalności za rok 1972 na walne zebranie w dniu 4.02.1973 roku, Archiwum Ochotniczej Straży Pożarnej w Dzikowcu.

31 Charakterystyka OSP..., poz. cyt.

32 Protokół z walnego zebrania z dnia 2.03.1986 roku, Archiwum Ochotniczej Straży Pożarnej w Dzikowcu.

33 Protokół walnego zebrania z dnia 17.01.1988 roku, Archiwum Ochotniczej Straży Pożarnej w Dzikowcu.

34 Charakterystyka OSP..., poz. cyt. 
organizacji z lokalną społecznością traktował bardzo poważnie. W czasie jego kadencji jednostka we współpracy z radą sołecką przystąpiła do odnawiania we wsi przydrożnych kapliczek. Kultywowana była również pamięć o zmarłych członkach, na ich grobach zapalano znicze z okazji Uroczystości Wszystkich Świętych ${ }^{35}$. W grudniu 2004 roku ówczesny prezes stanął na czele Społecznego Komitetu Ufundowania Sztandaru dla OSP Dzikowiec $\mathrm{w}$ 6o. rocznicę jej powstania. Czynnie uczestniczył w pozyskiwaniu funduszy od sponsorów, a także czuwał nad organizacją uroczystości poświęcenia sztandaru. Został on nadany straży w Gminie Nowa Ruda - jako pierwszej - w dniu 28 maja 2005 roku. W 2005 roku OSP Dzikowiec otrzymała status Organizacji Pożytku Publicznego, co pozwoliło uzyskać dodatkowe fundusze z tytułu 1\% przekazanego podatku. Dzięki tym funduszom strażacy sukcesywnie uzyskiwali środki ochrony indywidualnej, które były wykorzystywane $\mathrm{w}$ akcjach gaśniczych. W 2005 roku podpisane zostało porozumienie $\mathrm{z}$ trzema ochotniczymi jednostkami ochrony przeciwpożarowej z Czech. W ramach współpracy każdego roku organizowano zawody sportowe, towarzyski mecz piłki nożnej, dożynki czesko-polskie oraz obchody Nocy Świętojańskiej. OSP Dzikowiec zainicjowała też lokalne imprezy skierowane do najmłodszych i niepełnosprawnych - Spartakiadę Integracyjną oraz Spotkanie Mikołajkowe dla dzieci z Ziemi Noworudzko-Radkowskiej. Dla dzikowieckich uczniów w okresie ferii zimowych oraz letnich organizowali zajęcia tematyczne. Strażacy pragnęli rozwijać swoją jednostkę także w kwestiach związanych z działalnością ratowniczą. W styczniu 2007 roku na zebraniu sprawozdawczym została przyjęta uchwała o podjęciu próby wstąpienia do Krajowego Systemu Ratowniczo-Gaśniczego. Jego celem jest ochrona życia, zdrowia, mienia, środowiska poprzez walkę z pożarami i innymi klęskami żywiołowymi, ratownictwo techniczne, chemiczne, ekologiczne oraz medyczne. Doszło do kolejnej poprawy stanu wyposażenia. Jednostka ratowniczo-gaśnicza z Nowej Rudy przekazała samochód pożarniczy marki Jelcz, a Gmina Nowa Ruda zakupiła Magirusa wyposażonego w sprzęt ratownictwa medycznego, agregat prądotwórczy oraz maszt oświetleniowy. Dzięki staraniom nasza jednostka otrzymała profesjonalny sprzęt ochrony dróg oddechowych oraz ratownictwa drogowego. Uzyskała także 2 pilarki spalinowe do drewna marki Stihl. 
W roku 2011 prezesem OSP został Damian Sadowski, który swą funkcję pełnił do grudnia 2018 roku. Dzięki wytrwałej pracy i poświęceniu z końcem grudnia 2012 roku jednostka stała się członkiem KSRG. W międzyczasie we wsi pojawił się palący problem. Od lat w Dzikowcu rodziło się mniej dzieci. W związku z tym gmina podjęła decyzję o likwidacji z dniem 31 sierpnia 2012 roku Zespołu Szkolno-Przedszkolnego w Dzikowcu, w skład którego wchodziły szkoła podstawowa oraz przedszkole samorządowe. W związku z tym miejscowe dzieci zostałyby zmuszone do dojeżdżania do okolicznych miejscowości już od najmłodszych lat. Dzikowieccy strażacy ochotnicy to ludzie wykonujący różne zawody, którzy strażacką służbę pełnili społecznie. Byli lepiej przygotowani do niesienia pomocy poszkodowanym aniżeli ogół obywateli. Z własnej woli, przy pomocy finansowej sponsorów, ciągle doskonalili swą wiedzę oraz umiejętności, aby chronić i ratować ludzkie życie w sytuacjach ekstremalnych. Ponadto bliskie były im zagadnienia związane $\mathrm{z}$ prewencją przeciwpożarową. $\mathrm{W}$ poprzednich latach angażowali się w inicjatywy odpowiadające na potrzeby lokalnej społeczności. Mieszkańcy wsi pragnęli zachować szkołę i przedszkole. Potrzebowali do tego stowarzyszenia, które stałoby się organem prowadzącym. Strażacy stanęli przed dylematem. Nie posiadali zaawansowanego doświadczenia w sprawach związanych ze szkolnictwem. Mimo to jednak zaoferowali gest solidarności z lokalną społecznością. OSP od dnia 1 września 2012 roku stała się organem prowadzącym dla powstałego Zespołu Szkół Społecznych w Dzikowcu ${ }^{36}$. Miejscowe dzieci wciąż miały możliwość edukacji w przyjaznym i znanym środowisku.

\section{Podsumowanie}

Członkowie Ochotniczej Straży Pożarnej w Dzikowcu przez cały okres działalności jednostki starali się odpowiadać na potrzeby społeczności lokalnej. Podobnie jak członkowie innych tego typu organizacji kultywowali wartości humanitarne, pracę społeczną itp. Solidarność z osobami doświadczonymi przez żywioły skłoniła pionierów do założenia organizacji. Stanowiła także impuls do zdobywania kolejnego sprzętu oraz rozwijania umiejętności strażaków. Ochotnicy integrowali lokalną społeczność oraz wsłuchiwali się w jej potrzeby do tego stopnia, że społecznie wykonywali prace niezwiązane z pożarnictwem, takie jak przygotowanie placu pod ogródek jordanowski 
oraz odnawianie przydrożnych kapliczek. Ostatecznie, gdy gmina chciała zamknąć miejscową szkołę podstawową i przedszkole, OSP stała się nawet organem prowadzącym dla funkcjonującego do dziś Zespołu Szkół Społecznych w Dzikowcu.

\section{Bibliografia}

Charakterystyka OSP Dzikowiec, Archiwum Ochotniczej Straży Pożarnej w Dzikowcu. Kronika Ochotniczej Straży Pożarnej w Dzikowcu, t. 1.

Kuta S., Ochotnicze straże pożarne w Polsce Ludowej 1944-1975, Warszawa 1987.

Matusak P., Tradycje i profil ideowy ruchu strażackiego w Polsce, w: Zeszyty historyczne Zwiazku Ochotniczych Straży Pożarnych Rzeczypospolitej Polskiej. „Z dziejów Ochotniczych Straży Pożarnych", red. J. Gmitruk, P. Matusak, Warszawa 2007, t. 6, s. 9-39.

Matusak P., Trwatość idei Bolestawa Chomicza w polskim ruchu strażackim, w: Zeszyty historyczne Zwiazku Ochotniczych Straży Pożarnych Rzeczypospolitej Polskiej. „Z dziejów Ochotniczych Straży Pożarnych”, red. J. Gmitruk, P. Matusak, t. 7, Warszawa 2008, s. 7-17.

Pilch T., Refleksje nad spotecznymi ifilozoficznymiprzestankami ksztattowania się wspólnoty i społeczeństwa obywatelskiego oraz jego wybranych organizacji, w: Analizy Strategiczne Florian 2050, red. M. Zalewski, Warszawa 2020, t. 2, s. 88-103.

Protokół walnego zebrania z dnia 1.03.1970 roku, Archiwum Ochotniczej Straży Pożarnej w Dzikowcu.

Protokół walnego zebrania z dnia 14.02.1965 roku, Archiwum Ochotniczej Straży Pożarnej w Dzikowcu.

Protokół walnego zebrania z dnia 17.01.1988 roku, Archiwum Ochotniczej Straży Pożarnej w Dzikowcu.

Protokół zebrania miesięcznego Ochotniczej Straży Pożarnej z dnia 22.02.1946 roku, Archiwum Ochotniczej Straży Pożarnej w Dzikowcu.

Protokół z walnego zebrania z dnia 2.03.1986 roku, Archiwum Ochotniczej Straży Pożarnej w Dzikowcu.

Protokół z zebrania Ochotniczej Straży Pożarnej z dnia 27.01.1946 roku, Archiwum Ochotniczej Straży Pożarnej w Dzikowcu.

Rozkaz komendanta głównego $\mathrm{nr} 5 / 52$ z dnia 29 lutego 1952 roku w sprawie kobiet w ochronie przeciwpożarowej.

Rozporządzenie Rady Ministrów z dnia 14 sierpnia 1958 roku w sprawie uznania stowarzyszenia Związek Ochotniczych Straży Pożarnych za stowarzyszenie wyższej użyteczności. 
Rozporządzenie Rady Ministrów z dnia 29 października 1949 r w sprawie rozwiązania stowarzyszenia wyższej użyteczności Związek Straży Pożarnych Rzeczypospolitej Polskiej.

Sprawozdanie finansowe za rok 1964 oraz plan finansowy na rok 1965 uchwalony na walnym zebraniu w dniu 14.02.1965 roku, Archiwum Ochotniczej Straży Pożarnej w Dzikowcu.

Sprawozdanie z działalności za rok 1964 na walne zebranie w dniu 14.02.1965 roku, Archiwum Ochotniczej Straży Pożarnej w Dzikowcu.

Sprawozdanie z działalności za rok 1972 na walne zebranie w dniu 4.02.1973 roku, Archiwum Ochotniczej Straży Pożarnej w Dzikowcu.

Sprawozdanie z pracy OSP w 1946 roku, Archiwum Ochotniczej Straży Pożarnej w Dzikowcu.

Ustawa z dnia 13 kwietnia 1960 roku o ochronie przeciwpożarowej.

Ustawa $z$ dnia 4 lutego 1950 roku o ochronie przeciwpożarowej i jej organizacji.

Wykaz członków Ochotniczej Straży Pożarnej w Knurowie - stan z dnia 24.02.1946 roku, Archiwum Ochotniczej Straży Pożarnej w Dzikowcu.

Zarządzenie ministra spraw wewnętrznych z dnia 18 lipca 1957 roku w sprawie ustalenia statutu wzorcowego ochotniczej straży pożarnej.

\section{Abstrakt}

Solidarność ze społecznościq lokalnq jako motyw działalności członków Ochotniczej Strazy Pożarnej w Dzikowcu w latach I945-20I2

Ochotnicze Straże Pożarne do dnia dzisiejszego odgrywają istotną rolę w społecznościach lokalnych. W zakresie ich działalności od początku mieściły się nie tylko akcje ratowniczo-gaśnicze, ale również propagowanie wartości humanitarnych i patriotycznych, kultury, sportu. Dzikowiec to wieś w województwie dolnośląskim, w powiecie kłodzkim. Miejscowość dzieliła losy Ziem Odzyskanych. Po zakończeniu drugiej wojny światowej osiedlili się w niej Polacy, którzy starali się przetrwać w nowych dla siebie warunkach. Jednym z poważniejszych zagrożeń dla przybyszy był żywioł ognia. Sytuacja ta spowodowała spontaniczne powstanie w miejscowości Ochotniczej Straży Pożarnej końcem i945 roku. Początkowo opierała się ona na solidarności z sąsiadami znajdującymi się w potrzebie. Brakowało nie tylko wyposażenia, ale także uregulowania kwestii formalnych, takich jak wybór zarządu. Z czasem problemy te zostały rozwiązane. Znaczna część 
mieszkańców wsi znalazła zatrudnienie w okolicznych kopalniach. Kolejne władze jednostki starały się zwiększać możliwości zapewniania przez straż bezpieczeństwa mieszkańcom. Przyczyniały się do tego zarówno kolejne ćwiczenia oraz szkolenia, w których uczestniczyli członkowie organizacji, jak i uzyskiwanie kolejnych samochodów pożarniczych. Nie bez wpływu pozostał również rozwój techniki pożarniczej. W społeczną służbę w szeregach OSP zaangażowały się kobiety oraz młodzież. Największą rewolucję w działalności straży spowodowało widmo likwidacji miejscowego przedszkola oraz szkoły podstawowej. Wizja konieczności dojazdów dzieci do innych miejscowości w gminie skłoniła organizację specjalizującą się w pożarnictwie do podjęcia próby ugaszenia palącego problemu dotyczącego edukacji. W 2012 roku powstał Zespół Szkół Społecznych w Dzikowcu. Ochotnicza Straż Pożarna w Dzikowcu do dziś stanowi jej organ prowadzący, co jest ewenementem w skali kraju.

Słowa kluczowe

strażak, straż pożarna, działalność społeczna, ratownictwo, Dzikowiec, Gmina Nowa Ruda, Ziemia Kłodzka, Ochotnicza Straż Pożarna w Dzikowcu, Związek Ochotniczych Straży Pożarnych, Związek Ochotniczych Straży Pożarnych Rzeczypospolitej Polskiej, PRL, XX wiek, XXI wiek 
